\title{
Implementation of the strategy of sustainable development in the model of critical theory of society and education system
}

\author{
Lesya Chervona ${ }^{1 \varpi}$, Hanna Chornoivan ${ }^{2}$, Olena Grynko ${ }^{3}$ and Serhii Myroshnychenko ${ }^{4}$ \\ ${ }^{1} \mathrm{PhD}$ in Philosophy, Senior Researcher, Leading Researcher of Department of University-Society \\ Interaction Institute of Higher Education of the National Academy of Educational Sciences of \\ Ukraine, Kyiv, Ukraine \\ ${ }^{2} \mathrm{PhD}$ in Education Sciences, Academic Secretary, Senior Researcher in Department for Integration \\ of Higher Education and Research, Institute of Higher Education of the National Academy of \\ Educational Sciences of Ukraine, Kyiv, Ukraine \\ ${ }^{3} \mathrm{PhD}$ in Philosophy, Assistant Professor of philosophy of Kyiv National University of Construction \\ and Architecture, Kyiv, Ukraine \\ ${ }^{4}$ Senior Lecturer, Department of Management, Information and Analytical Activity and European \\ Integration of the National Pedagogical Dragomanov University, Kyiv, Ukraine
}

\begin{abstract}
The call for democratic reconstruction of education should contribute to the development of the acquisition and use of knowledge and thought of as a response to emerging technologies and trends in globalization. In particular, be aware that nowadays some unfair terms communities, individuals are privileged in having access to technology, a high-tech skills and cultural capital than the less privileged communities. One way to overcome this abyss of a whole complex of new classes of inequalities, gender, race, education is restructuring so that all students have access to new technologies and new knowledge in the system democratized education and training process. Hegelian dialectics can help the efficiency of the relationship between students and teachers today in a situation where there is a lack of cultural, social experience as well as the specific subjectivity between groups, nations and generations. Teachers, students, and citizens must recognize this potential conflict and consolidate work to overcome these conflicts, making these actions more productive. Overall, the democratization of education can be enhanced in part by increasing elaboration and interactive forms of education, including such as distance education, the development of collective educational websites, online discussions and a scientific online community, shared internet research projects. But the restructuring of education also requires targeted public, values education, literacy cultivation. For teaching and learning books and printed materials based on multimedia and Internet materials should be considered as an additional, rather than as the primary means of democratization of education.
\end{abstract}

\section{Introduction}

The growth of political, economic and cultural conflicts, terrorism, wars requires education to research issues of war and peace, the use of achievements in conflict resolution through mediation, which is an important part of the democratic program of social development. The growth of cultural conflict makes all the more important understanding

Y Corresponding author: zinchenko.72@gmail.com 
of what is important in today's globalized world, the formation of empathy and understanding of others, seeing how the humanistic values of tolerance and education, the struggle for peace and justice can be established in the present situation [1]. Critical pedagogy in this context must also deal with a difficult issue to overcome cultural differences, understanding, and develop a convincing model of democracy, which will include the development of existing and marginalized groups and conflict between different communities and culture [2]. It's important noted that critical theory seeks to restore humanized content and meaning of education is not for the introduction of capital values of industrial and high technology, but above all, a radical democratization of education in order to achieve the goals of progressive educators, in particular, such as Dewey, Freud, Illich in education, research that will contribute to the development of personality citizenship and community, social justice and strengthening democratic participation in all kinds of life. Over the past decade there has been persistent attempts to impose neoliberal policies on education, the desire to reorganize the school under a business model implementation rigidly standardized curriculum. primitive testing methods, distorting the meaning and purpose of pedagogy. This neo-liberal program is catastrophic for the content of education and training and the critical theory of education in this context should be seen as a critique of neoliberal restructuring of education and in this sense it is necessary to propose an alternative concept and practice of education, training and social development [3]. Globalization and the technology revolution have be used for a radical restructuring of education and support for members of a radical pedagogy training conditions so that they can offer their models of pedagogy and reconstruction of education for its service to democracy and progressive social change. Although strictly necessary to criticize neoliberal model, it is also important at the same time offering them an alternative. Therefore, you must be accompanied by a demand for new knowledge and restructuring education program of democratization.

The modern concept of «critical social philosophy of education» examines the modernization of social, economic and political development and the potential of anthropological-psychological structure of human values and normative dimension of contemporary globalized society world reformation strategy in society, education and management, globalization and their institutionalization processes and perspectives humanization of education, administration, education [4,5]. Critical Theory of Education, which develops in recent years within the postmodern update traditionalist educational paradigm requires researchers a new view on the social structure of education, a special analysis of the context of solving educational problems. It requires a deep analysis of the relationship between teaching and administrative components of democratization. But it specifies only the general ideological and methodological framework addressing issues of democratization of education, leaving unanswered questions about the specific terms of such decision. Changes in the interpretation of the democratic social order led to the need to find mechanisms and conditions for the implementation of the idea of democracy in educational institutions, the need for new research and practical advice based on the current systemic vision of education for school allocation as a key element of the system, the contextual analysis of individual successful attempts of democratization. Thus, the research problem in a generalized sense is to theoretically determine and verify the experience of such approaches to democratization of education that would overcome the abovementioned difficulties and solve the problem of coherent implementation of the idea of democratic education.

\section{Research methodology}

In current trends of social development with ever more general need arises the need solving in theoretical and practical terms, the problem of civic institutional democratization, 
including systems management, and education and realize the vision of a democratic public education and enlightenment.

Modern management, philosophy and sociology of education, developmental psychology suggest that the mechanisms and conditions for the implementation of pedagogical ideas are reflected not only in the formal organizational structures and training programs. A key role in pedagogically meaningful social affairs educational institution plays a set of explicit and implicit factors - an informal organization of schools forming objective (institutional) context of democratization of education. However, the existing studies, this task is not fully resolved. Therefore it is important to answer the question of what institutional context can be given in school to become a condition of its conversion to an open democratic community? Significant severity of the theory and practice of democratic education is the fact that existing studies on democratization listed areas are considered on the basis of understanding of democracy, designed for advanced social institutions at the beginning of the century. Therefore, the implementation of the said idea requires, first, clarify ideas about democracy under contemporary socio-cultural situation and, secondly, the development trends of transformation of education as a social institution of specific rights, exposing idea of democracy can be implemented. The solution of this problem makes appeal as a social theory that clarifies the modern idea of democracy and the theory of education. Contemporary social theory offers a new understanding of democracy (critical or pluralist model), different from the traditional liberal or asocinianism, the essence of which is to overcome the alienation of the individual from society and culture, diversity and globalization.

\section{Results of the research}

As social philosophy, philosophy of science, global studies, and management are discussed in «critical social philosophy of education» as the basis of institutional and ideological foundations of civil process, the educational process is presented in this context as an object of management and socio-philosophical analysis. Therefore, researchers who belong to this ideological school, analyze the main trends of research institutionalization of civil society, education and training in context of global humanistic philosophical principles, values and management models and types / levels of government. The system of quality education, effective public education at various levels have to anticipate both and effective system of social management, guarantee the existence of which is in turn developed institutionalized civil society, and the formation of which requires not only the rule of law as its premise, but a completely new concept of learning, based on the social model philosophy of education [6]. However, only a developed and stable democratic system of education and public education enables efficient formation of civil society, the rule of law is the foundation of a stable democratic government and authoritative power [7].

Critical theory management of education should be based on a critical theory of society, which is conceptually analyzes the features of actually existing capitalist societies and their relations of domination and subordination (oppression), conflict and the prospects for progressive social change and transformative practices that make projects more complete, freer life and democratic society. Criticality theory means a way of seeing and understanding, building categories, making connections, reflection and participation in practice theory, theory of withdrawal of social practice. Critical Theory is interdisciplinary, involving analytical criticism arsenal of different academic science and transdisciplinary theories of various branches of knowledge for making multicultural objective view of the present and future society. Critical theory is a boundary crossing, interaction and mediation, combining different aspects of social life in complex projects of normative historical thinking. Her metatheory so most models contain a holistic education that integrates a variety of topics that are dialectical unity, not dividing the material in to knowledge. 
According to the critical theory of education in today's society there is thus a fundamental mismatch between education and life experience, expectations of the older generation regarding labor and new social conditions and previous organizational forms of economy and culture, as opposed to the new digital and multimedia on based culture and fusion global economynt.

The concept dates back to the 1970's and 1980's in a socially-critical studies P. Freire, H.Marcuse, Ch.Reych, I.Illich, R.Prebisch, K.Leech, R.Lichtman, R.Jacoby and others. It also uses some narobky G.Deleuze, F.Guattari, M.Foucault, J.Lacan. Methodological and analytical principles in this area of research based on critical theory and social studies formed on the basis of the concept of «social deliberative», «social subsidiarity», Liberty reflex communitarianism, according to which the subject and the object is interacting factors among the entire set of social practice at the institutional level, this stage of its historical development. interdisciplinary Now this trend is headed philosophers, political scientists, economists, cultural D.Kellner, I.Benjamin, R.Lichtman, R.Jacoby, P.Orban, D.Cooper, A.Jappe, A.Badiou, M. Debes, G.Miaret, S.Zhyzhek, R.Kurz, M.Bookchin, P.Cockshott, A.Cottrell, R.Danneman, R.Scholz, E.Lohoff and S.Miller, others. They seek to expand the existing understanding of the theory and practice of education and social philosophy, management of the achievements and challenges of globalization processes, the institutionalization of civil society, their role for social life and social cognition in the context of education and social analysis of the phenomena of education, upbringing and training. Social philosophy, philosophy of science, global studies, and management are discussed in "social philosophy of education» as the basis of institutional and ideological foundations of civil process, the educational process is presented in this context as an object of management and socio-philosophical analysis. In this concept the analysis of social, philosophical and managerial aspects of the models and methodologies of modern educational philosophy and management educational process.

When using the term «critical theory» (eg, education) is generally understood methodological developments of the Frankfurt School of Social Research, but the understanding of critical theory is broader than the version developed «Frankfurters». In the context of theorizing and reconstructing education for the modern era, it is necessary to include the tradition of critical pedagogy, post-structuralism and pragmatism. The last topic covered critique of reason and of liberal democracy in particular the French version of «posttheory» But it is also necessary to consider the critical theory research on globalization, society, education, gender, race and subjectivity have developed a wide range of theoretical entities in recent years. These topics can enrich critical pedagogy and help with the project of democratization and reconstruction of education to ensure that the goals of social justice and progressive change can provide the pedagogy and practice of education. Metateoretychne I use the term «critical theory» as a concept of opening this project to show the critical dimension of theoretical aspirations and political dynamics that seek to link theory and practice. The concept of «criticality» is synoptic in a wide range of themes and issues «critical» in ancient Greek verb meaning krinein, which means to distinguish reason and judgment, and «theory» in the sense of the Greek noun contemplation to which the way of seeing and contemplation. Of ancient Greek criticism is rooted in everyday life and is an example of Socratic practice study of social life, its institutions, values, and dominant ideas and his own thoughts and actions [8].

Criticism has become central to the project of the Enlightenment as a critique of power and legitimation of his intellectual and political positions. According to the Kantian sense of criticism, for example, want to question all the ideas of reason, morality, religion, aesthetics, and other dominant ideas to see how they can be justified and institutionalized. Kant criticism aimed at the autonomy of prejudice and unfounded ideas and demands rigorous reflection on their background and the major positions and arguments to support 
their position. Critical theory is also based on the Hegelian concept of criticism, criticism unilateral position (such as technophobia against technology) and development of a complex dialectical perspectives that reject and unsubstantiated, erroneous or oppressive features of the item at the same time creating a positive and liberating aspects. Critical theory takes the Hegelian concept by developing a coherent theory to try to understand the totality of the industry, however, assuming that it is important to make associations and formulate conflict, breaking idealistic or reductive theories in general.

A critical theory of education also draws on Marxian critique, stressing the importance of critique of ideology and situating analysis of a topic like education within the dominant social relations and system of political economy. The Marxian project systematically criticized the assumptions of an established hegemonic discipline, as in Marx's critique of political economy, and constructed an alternative theory and practice to overcome the limitations and oppressive features of established institutions and systems of production. Marxian critique involves radical examination of existing ideologies and practices of education and the need for pedagogical and social transformation to free individuals from the fetters of consumer capitalism and to help make possible a free, more democratic and human culture and society. Marxian theorists like Antonio Gramsci criticized the ways that Italian education and culture reproduced ideologies of the bourgeoisie and then fascism and called for a counterhegemonic cultural project that would encompass alternative institutions from schooling to theater to journalism to help construct a socialist and democratic society. In our time, as Charles Reitz has demonstrated, Herbert Marcuse carried out sustained criticisms of the existing system of education as a mode of reproducing the existing system of domination and oppression and called for counter-institutions and pedagogies to promote democratic social transformation and the full development of individuals.

Building on this tradition in the critical spirit of Hegelian philosophy, and classical philosophy of education can help in the project of reconstruction and democratization of education and society, but some idealist, elitist and repressive elements of classical and modern pedagogy must be rejected. Critical Theory of Education provides a normative dimension theory as practice building life and educational alternatives available. Development of this educational model applies regulatory developments classical philosophy of education from the Greeks through John Dewey and critics of classical western education such as Ivan Illich [9,10] and Paulo Freire [11-13]. In Greek philosophy means love of wisdom (philo-Sophia) and the practice of philosophy - a Paideia (formation) and development of man and citizen. In the early twentieth century, John Dewey, headed direction, which has developed the most stable premise of progressive education, relationship education and democracy. Dewey argued that there can be no democratic society without a democratic education that everyone should have access to education and that education is the key to democracy, and thus social welfare. Dewey was an advocate of a strong, egalitarian and participatory democracy, where everyone takes part in social and political life. For Dewey, education is the key to working democracy, so as to reasonably participate in public and political life, to be informed and educated to be able to be of high quality and competent member of the national democratic life.

\section{Conclusions}

The call for democratic reconstruction of education should contribute to the development of the acquisition and use of knowledge and thought of as a response to emerging technologies and trends in globalization. In particular, be aware that nowadays some unfair terms communities, individuals are privileged in having access to technology, a high-tech skills and cultural capital than the less privileged communities. One way to overcome this abyss of a whole complex of new classes of inequalities, gender, race, 
education is restructuring so that all students have access to new technologies and new knowledge in the system democratized education and training process. Hegelian dialectics can help the efficiency of the relationship between students and teachers today in a situation where there is a lack of cultural, social experience as well as the specific subjectivity between groups, nations and generations. Teachers, students, and citizens must recognize this potential conflict and consolidate work to overcome these conflicts, making these actions more productive. Overall, the democratization of education can be enhanced in part by increasing elaboration and interactive forms of education, including such as distance education, the development of collective educational websites, online discussions and a scientific online community, shared internet research projects. But the restructuring of education also requires targeted public, values education, literacy cultivation. For teaching and learning books and printed materials based on multimedia and Internet materials should be considered as an additional, rather than as the primary means of democratization of education.

In addition, the critical social and philosophical theory of education will involve merging class-based Socratic discussions of research projects that will combine oral, written, multimedia and cultural forms of the learning process, not favoring any of them. Some educators still insist that direct dialogue in the classroom / class is the alpha and omega of quality education, but seeing for classroom dialogic extremely productive, do not need to fall into a false fetysh any of the training shapes. This also applies to new media models of education. Rather, the task is to build in quality development in all experimental and more all these aspects of the educational process on civil-social restructuring and democratization of education. Consequently, the reconstruction of education on the grounds that the socio-economic, cultural and material conditions of life and labor vary with the social development of the mind is the answer to the great transformation of our time. Critical Philosophy of Education is committed to providing a radical critique of existing education in so-called Western models of democracy, creating a progressive alternative models.

In this context, the proposed integrative metatheory that is Based on classical and contemporary sources, concepts, committed to a comprehensive understanding of the phenomenon and the reconstruction of education. One of the main objectives in the democratization of education today, therefore, is to engage education for the restructuring and democratization of society and reflect the changes in the conditions of life and thinking, experience and transformation of subjectivity in the context of the technological revolution and globalization. It involves using technology to democratic reconstruction of education and the promotion of progressive social and political change without the help of the neoliberal model values and capital social order.

Based on this premise, in the long run it allows to develop the philosophy of education to develop a more inclusive vision of philosophical education to speak directly to issues of democratization and changing social relations in the direction of equality and social justice. As social circumstances are constantly changing, critical theory of education must be radically addressed to historicism, trying to reconstruct education and its institutions as social development conditions and create educational alternatives in terms of needs, problems and opportunities of specific groups of people in specific situations. However, in terms of philosophical and normative understanding and social criticism also necessary to use an active effort on the reconstruction of education and society, the social vision of what education and life can be and what their specific limitations in existing societies.

Thus, social and philosophical critical theory of education involves the study of education in a public context for understanding how the radicalization of democratic education can help to significantly change society and its essence. 


\section{References}

1. V. Zinchenko, Am. Res. J. Humanit. Soc. Sci. 4, 1 (2018)

2. A. D. Gitlin and J. Ingerski, Int. J. Crit. Pedagog. 9, 7 (2018)

3. R. Hall and M. Pulsford, Power Educ. 11, 241 (2019)

4. Z. Leonardo, Educ. Res. 33, 11 (2004)

5. Ł. Kierznowski, Stud. Logic, Gramm. Rhetor. 52, 133 (2017)

6. V. Sintschenko, Sozial Wirtschaft Und Die Entwicklung Der Zivilgesellschaft. Soziale Wirtschaft (CB-Verlag Carl-Boldt, Berlin, 2010)

7. F. Paul, Teachers As Cultural Workers: Letters To Those Who Dare Teach (Edge, Critical Studies in Educational Theory (Westview Press, New York, 1997)

8. D. Kellner, Critical Theory, Marxism, and Modernity. (, Md.: Polity Press and John Hopkins University Press, Cambridge, UK and Baltimore, 1989)

9. I. Illich, Geuder (Panteon books, New York, 1982)

10. P. Freire, A Pedagogy for Liberation: Dialogues on Transforming Education (Bergin \& Garvey Paperback, New York, 1986)

11. P. Freire, Pedagogy of Freedom: Ethics, Democracy, and Civic Courage (Critical Perspectives) (Rowman \& Littlefield Publishers, New York, 2000)

12. P. Freire, Pedagogy of the Heart (Continuum, New York, 1998)

13. P. Freire, Pedagogy of the Oppressed. (Continuum, New York, 1996) 